What Your Country Can Do for You: A Typology of Religious Feminist Strategies

Elisheva Rosman

A significant volume of scholarship dealing with religion and gender assumes that gender equality is incompatible with modernity and rights, and with state endorsement of religion (Stopler, 2005; Schnabel, 2017; Shachar, 2005; Ozcetin, 2009; Avishai, Jafar and Rinaldo, 2015:5-6; Donahoe, 2017; Nyhagen, 2019; Llewellyn and Trzebiatowska, 2013; Razavi and Jenichen, 2010; UNRISD, 2009; Irshai, 2010). Therefore, according to this school of thought, demands from the state regarding intervention within the relationship between religious institutions and believers are illegitimate. According to this view, what happens between religious frameworks and believers is private and has nothing to do with the state (Nyhagen, 2019:9). However, despite this position, at times, believers do call upon the state to involve itself within this relationship. The most prominent of these cases, usually involve religious feminists ${ }^{1}$ who may turn to the state in order to achieve their objectives vis-à-vis their respective religious establishments. ${ }^{2}$

Despite the observation that such demands have become more and more prevalent (as demonstrated, for example in: Watling, 2002; Yanay-Ventura, 2016; Irshai, 2012; Israel-Cohen, 2012), scholarship has yet to classify when and how they happen and what form they take. This article seeks to contribute to the conceptualization of this relationship and - within this context - to examine the expectations religious feminists have from the state, in their quest for equality in the religious sphere. It sets out to classify and categorize the strategies used by religious feminists in order to elicit change, and to identify within these strategies what role they expect the state to play. Drawing on examples from the Israeli case study, where religious feminists have contested the religious authorities using multiple strategies, the paper maps out a series of typologies that provides a theoretical framework for considering how religious feminists may operate in different scenarios and the expectations they have for the state in calculating routes for advocating their causes. Using data to create a typology, even as an initial one, can be helpful in cases when the field is underdeveloped and is in need of preliminary 
tools for analysis. The current paper sets to do this with hope of continuing the typology with other cases in the future.

While much has been written about religion, gender, and the state individually, there is a dearth of scholarship addressing the intersection of all three topics (Aune and Nyhagen, 2016). This is true for international scholarship, as well as case-specific research. Numerous attempts to put together collections on gender and religion, religion and the state and gender and the state exist. These usually focus on a defined aspect of the interaction between actors, such as: fundamentalism and gender (Hawley, 1994); religion and feminism (Castelli and Rodman, 2001; Haddad and Esposito, 2001); religion and gender (Avishai, Jafar and Rinaldo, 2015; Okin, 1998; 2002); religion and the state (Kuru, 2009; Monsma amd Stoper, 2009; McLoughlin and Cesari, 2016; D’Costa, et. al, 2013; Cohen and Laborde, 2016); gender, religion and International Relations (Donahoe, 2017). Additionally, these projects usually have a disciplinary focus and view the issues through a defined field such as sociology (Avishai, Jafar and Rinaldo, 2015), anthropology (Moors, 2009); law (Shachar, 2005; Hawkins, 2012; Ahmed, 2010, Moors, 2018), feminist thought (Haddad and Esposito, 2001), political theory (Laborde and Bardon, 2017; Laborde 2017; Okin, 1997).

As noted, a considerable amount of scholarship dealing with religion and gender assumes that gender equality is incompatible with the state endorsement of religion and demands from the state regarding intervention in this field are illegitimate (Nyhagen, 2019). For example, Stopler (2005) described the conflict between the various components of the religion-gender-state relationship and sees religion as a threat to women's rights. This view is not an isolated one (as noted in: Casanova and Phillips, 2009). According to this school of thought, it is necessary that the state stand unequivocally on the side of gender equality and not involved itself in gender-religion issues. Essentially, this means that only secularism and privatization of religion can bring about gender equality and protect women's rights. Religion is always a negative influence and must not be part of the equation. ${ }^{3}$

Additional scholarship has highlighted the tension between religious and secular feminists and between religious women and feminism - real or imagined (Ozcetin, 2009; Nyhagen 2019; Llewellyn and Trzebiatowska, 2013). 
A notable exception to this lack of engagement of the relationship between the state, gender and religion is Herzog and Braude's volume (2009). This book was the first attempt to map out the field and offer a cross-country study of all three factors. Another study attempting to address the intersection of gender, religion, and the state, is Htun and Weldon's background paper for the World Development Report on Gender Equality (2012). While this paper viewed the topic through the prism of family law, it attempted to look at cases where religion also affects the interaction between gender and the state, and did so by looking at a broad range of countries.

Similarly, in 2007-2009, the UN Research Institute for Social Research (UNRISD) conducted a project on the topic of Religion, Politics and Gender (2007). The project was cross-country, but mainly historical. It remains the main corpus of research on the topic and has not been replicated since. One of the most important publications originating from the project is Casanova and Phillips (2009). While they do not offer a conceptualization, their monograph discusses practical implications of the interaction between the state, gender, and religion and suggested that clear-cut models, such as privatization, are not always the most desirable solution when striving for realization of equality and protection of civil rights. In other words, calling upon the state to involve itself in gender-religion issues is not always negative and scholarship still lacks the proper tools with which to approach this topic. Importantly, their point of departure is that religion is a political force that is here to stay and that it is not always detrimental to equality, rights, and civil liberties. All of the above, stress the fact that religious feminism and its relationship with the state is not only an intersectional topic (YuvalDavis, 2006; 2007; 2011), but is also very timely.

At the same time as the debate regarding the state and its role regarding the relationship between religion and women's rights continues, religious feminism has grown and accumulated speed, both socially and politically. There has been a shift in the relationships between religious women and the religious establishment, and this aspect has only begun to appear in scholarship. Religious women do not feel they must choose between religious observance and their right to be full members in both general society and their own communities. They see their demands for rights and equality as legitimate and worthy, and pressure the religious establishment from within to accept change and the 
possibility for change. They are also comfortable enough with their demands, that they are willing to risk a possible rift with their social group and at times petition the state to become involved in these seemingly internal issues. For example, to rule in favor of abortion in certain cases, or to force religious divorce. At the same time, religious feminists do not wish to become secular. They demand that the secular sphere recognize their needs and respect their religious rights, such as covering their hair or bodies in public, or recognizing their wish for gender-specific areas. Here too, they sometimes turn to the state for support. While, as in many fields dealing with religion, it is clear that strategies are also individual (Bowie 2016), there are also generalizations that can be made.

Due to the lacuna in scholarship, there is a lack of terms with which to approach this entire topic. What do religious feminists expect from the state? Are there strategies used in this relationship that can be detected? When is a particular strategy more likely to surface? Can we categorize strategies? These are only some of the more basic questions this new field raises. Since this is a new field, there is a need to borrow terms and strategies from other fields and building upon them, as demonstrated below.

The current paper puts forward a preliminary typology for strategies religious feminists use vis-à-vis the state. This typology is expected to make a theoretical contribution to the field, focusing the debate and enabling research to delve deeper into the relationship between religious feminists and the state. Since it is a preliminary typology, it seeks to begin the academic discussion regarding these strategies, with hope that future studies will test it using other case studies and refine it further.

A caveat is in order here. Religious feminists are not a homogenous group, even within case studies or specific countries or religions. Not all of them see themselves as feminist (although they may be in all but name). Others feel that secular feminists accuse them of being "bad" feminists due to their religious beliefs: how can a woman who covers her hair or face be "free" and not part of an oppressing patriarchal system? Religious feminists react differently to external responses to their actions. Some reject feminist labels, while still behaving and using strategies that are clearly influenced by feminism. Some wish to confront secular feminists and force them to accept religious feminism as a 
viable entity. Others, feeling shunned and ostracized, may eventually turn to more fundamentalist interpretations of religion (Okuyan and Curtin, 2018).

Likewise, not all religious feminists belong to formal organizations. In the era of social media, they do not always feel the need to join such organizations. At times they band together in ad hoc groups in order to push forward a specific initiative; returning to their lives when the issue is resolved. These differences require a better understanding of the field and recognition of strains within the collective is crucial. However, here, too, generalizations are needed if a common conceptualization is to be created. In this respect, the current paper will allow generalizations concerning the specific case study in order to define strategies, with hope that future studies will use the strategies depicted here as a point of departure and build upon them.

As noted, this paper will use examples from a specific case study, the Israeli case. Specifically, it will focus on Jewish Orthodox feminists, who are the largest group of religious feminists in Israel. This is by no means an exhaustive case. However, it holds a large variety of examples that can be used in the current typology.

The typology proposed is based on following religious feminist discourse over the past 15 years focusing on five tracks: traditional media (national and sectarian); social media; religious responsa; legal cases; and legislature. Traditional media included national newspapers in Israel (Haaretz, Yediot Aharonoth, Maariv and Makor Rishon), as well as national-religious publications (the weekly Besheva, as well as weekend religious pamphlets such as Olam Katan, Shvei'i, and Matzav Haruach). Social media included homepages and facebook pages of influential religious seminaries such as (but not limited to) Elie, Atzmona, Har Etzion, Midbara KeEden, Mideshet Lindenbaum, Ein Hanatziv, and Tzahali. The main religious activist (not necessarily feminist) organizations of Kolech, Itim, Mercaz Tzedek LeNashim, Yad LaIsha, Tzohar, were also monitored. Additionally, the very active facebook communities of "I too am a *religious* feminist with no sense of humor" and "Halakhic Feminists" (both in Hebrew) were monitored since they began. Religious responsa (written and electronic) of influential rabbis as well as religious and sectarian pamphlets published on topics relevant to women's rights were collected since 2001. Legal cases regarding issues involving 
women's rights within the religious sphere were likewise collected and reviewed. While this was done systematically since 2001 , earlier cases were used as well. ${ }^{4}$ Similarly, legislature pertaining to church-state relations (most specifically personal status legislature) and women's rights was also collected.

In order to construct the typology, it was important to examine developments over a substantial period of time using content analysis, and to do so from a "bird's eye view" of the material. In addition, the author was a participant-observer of many of the incidents described in the paper. ${ }^{5}$

Data was analyzed to see what strategies could be detected (if any). After general tendencies were identified, these were compared to possible strategies in existing literature or terms that could be borrowed from other fields. If similarities were found, and characteristics could be classified according to existing literature, the strategy detected was included as a possible category. If not, the strategy was filed as a "wild card" to be reexamined. At the end of the process, identified strategies were organized and unidentified strategies reexamined and reclassified. After repeating the process several times, the proposed typology was reached. In this respect, defined religious feminist organizations were not analyzed individually. Rather, the focus of analysis were incidents where the state, religious feminists and the religious establishment came into play. Since the typology is still being developed, and terms are still being shaped, this approach seems best.

After introducing the Israeli case, the paper will present the proposed typology of strategies, borrowing terms from similar fields. It will conclude with some suggestions for further development of the field.

\section{The Israeli Case}

Israel is a modern democratic state that identifies Judaism as its state religion. While Israel cannot be considered a theocracy, relations between civil matters and religious matters are complicated, due to the Ottoman Millet system. The Millet system, used in the pre-state era, is still upheld in many ways regarding the way the state relates to religious activities. It enables the state to recognize religious 
denominations, and, in turn, these religious denominations enjoy exclusive jurisdiction on issues of personal law. In addition, in the Israeli version of the Millet system, beyond jurisdiction over personal law, most recognized denominations are also entitled to governmental-provided funding. For example, the state pays the salary of clergy, such as Jewish and Islamic judges in religious courts. Thus, despite Judaism being the majority religion, the State recognizes several religious denominations, and their right to run their community affairs internally. Despite its tolerance towards different traditions of Christianity and Islam, it is more ambivalent to non-orthodox Jewish denominations (Reform and Conservative Judaism) ${ }^{6}$ (Barak-Erez 2009; Leibman and Don Yehyia 1983; Neuberger 1999). By using its funding powers, and by granting only specific Jewish authorities the rights to make legal pronouncements on religious matters such as conversion, marriage etc., the ties between the state and the recognized denominations is further solidified. Civil matters are handled by government agencies and apply equally to all the civilians of the State, irrespective of gender or religion.

Religious feminists in Israel are predominantly, though not exclusively, Jewish. These women are the focus of this article. They are Jewish women who are primarily active in issues concerning women's rights and roles in a religious context. These include personal status (marriage and divorce), as well as intra-religious issues, such as allowing women to hold religious positions (for instance, to be ordained as religious desicors - poskot halakha), women's participation in the religious public sphere and autonomy in religious issues (prayer at the Western Wall and use of ritual baths), and women's roles in the synagogue and in the context of religious education.

At their core, these are indeed intra-religious issues, since they concern how a specific religion regulates practices within itself. However, since many of these issues are controlled by the state to varying degrees, change cannot only take place within the religious sphere alone or even within the private sphere of individual believers (Halperin-Kaddari 2000). For example, religious baths (mikvaot) are built by the state and regulated by it. The state has the power to decide who the gatekeepers for the baths will be and how they will behave towards the women using the baths (as shown by Perez and Rosman 2019). 
In the past decade, religious feminists have successfully brought about change in women's issues using multiple strategies and frequently turn to parliamentarians and to the courts for assistance (Perez and Rosman 2019). At the same time, it seems that religious feminists in Israel use multiple strategies vis-à-vis their religious establishment and the state and do not confine themselves to legal action alone when facing it.

Another aspect highlighted in the Israeli case, is that it showcases a relationship where church-state relations have created serious dilemmas for all women, and religious feminists are vocal and accepted (for the most part) by the general feminist movement in Israel. They are not afraid to take on the religious establishment in the legal and political spheres and to call on the state for support. That said, they are not a monolithic group and use different strategies in order to affect change. Many of them are not part of any formal organization. As noted above, in the age of social media, they do not always need an organization in order to act. ${ }^{7}$

Additionally, in the Israeli case, religious feminists are supported many times by secular feminists a phenomenon that is somewhat less apparent in other cases, as either the theocratic nature of the state reduces the power of secular feminists, or the separation between church and state marginalizes religious feminists (Okuyan and Curtain 2015; Leszczynska 2016). Coupled with the unique churchstate relationship it maintains, Israel serves as an interesting case study. Using this case, we may now turn to mapping out possible strategies religious feminists use and their expectations from the state.

\section{Religious Feminist Strategies used versus the Religious Establishment and Expectations from the}

State.

Most issues that religious feminists focus on, concern their relationship with the religious establishment, rather than attempting to impose changes in the secular rule of law. Consequently, their main adversaries are primarily religious figures - usually of the reactionary bent - and institutions who oppose change in general and women's rights in particular. In this respect, the strategies religious feminists utilize are, first and foremost, grounded inside the language and 
politicking of the religious establishment - since receiving its support, or at least acceptance of their demands is the least hostile path to change.

At times, religious feminists' most powerful recourse is the state. The women are most likely to turn to the state when they expect it to actively or passively support their demands against the religious authorities. Yet the involvement of the state can also undermine the feminists own efforts, and they therefore sometimes prefer the state, even when it may have an interest in the case, adopt a "hands off' position and distance itself. The nuances in these different positions can be understood through an examination of the strategies religious feminists apply, the circumstances when they are most likely to be utilized, what role the state plays within each and, finally, how in practice a given strategy is implemented.

A typology of strategies has not been attempted before. Therefore, the current typology borrows from other, parallel and tangent, fields: revolt and rebellion are borrowed from Susan Sered's (1997) work on secular feminism, and exit is borrowed from Allen Hirschman's work (1970; 1974) on exit, voice and loyalty. Bargaining is borrowed from Deniz Kandiyoti’s work (1988; 2005). In addition, the proposed typology suggests independent categories of leveraging and acceptance. Since this is a developing typology, it does not necessarily fit into recognized forms of typologies (Elman 2005), and is expected to evolve. Nevertheless, as previous studies point out, it is important to create typologies even in this limited form (Perez 2020).

\section{a. Rebellion and Revolt}

Borrowing from Susan Sered's work (1997) on secular feminism in Israel, indicates how religious feminists recraft traditional feminist tools for their own ends. Sered established that when focusing on women and religious change, women bring about change through rebellion or revolution. Sered demonstrated that women who turn against religious authority prefer rebellion, seeing it as "a situation in which subordinates turn against a leader without revolting against the authority of the office he occupies" (Sered 1997,2), as opposed to revolution, which "sets out to change the 
fundamental rules of the game" (Sered 1997,3). Sered examines these strategies within the dynamic of gender and religion alone, without the involvement of the state as an actor.

When choosing rebellion as a strategy to use against the religious authorities, religious feminists do not turn to the state. When used, rebellion concerns an attack on a specific stand taken by a religious authority. For example, when demanding women be allowed to play a more active part in religious life, religious feminists work within the framework of religious legal law. In this case, they point to historic precedents where women were allowed the exact religious freedom demanded (or one similar), indicating that those who oppose this right are in fact interpreting religious codes incorrectly. The problem is not the religious sphere itself, but the way certain religious leaders interpret religious law or behavior.

In most cases, since this is an internal strategy (concerning behavior within the religious community) and does not involve civil rights but only religious ones, nor does it involve women who are not religious, religious feminists have no expectations of the state. Usually, they prefer the state not interfere, but rather detach itself and allow religious feminists to negotiate for change internally. This is important because it enables religious feminists to demonstrate they are observing the internal "rules of the game" and not involving outside actors. They are not airing religious "dirty laundry", in public and their demands are keeping within the agreed-upon framework that the religious establishment accepts. It is only when rejection of these demands for internal change have implications for civil rights that religious feminists expect the state to protect them, as described below.

Rebellion is the preferred strategy in cases where the issue at hand is internal (within a primarily religious context) and is perceived as being predominantly within the realm of the religious authorities' sphere of influence (due to the ability to argue that the issue contains a dimension of religious law). Examples of rebellion in Israel include the push to allow for women to act as religious desicors, the social conventions allowing for women to study religious texts (primarily Talmud) previously seen as an exclusively male sphere of study, and the establishment of women's religious seminaries (midrashot) as a result. Religious feminists strove to portray these actions as religiously 
permitted per prior Jewish tradition, and that the religious establishment misunderstood and misinterpreted the ban on the roles women may play in this sphere. These changes were not painted as a movement against Orthodox Judaism and indeed in many cases the women who joined the call for women's religious studies did not always portray themselves as feminists. ${ }^{8}$

This effort called for change from within and is a bottom-up movement that has evolved over many years. It can be seen as "rebellion" in the context of strategies used, since it is not questioning the legitimacy of orthodoxy in any way. It posits that the current religious establishment presents a religiously-illegitimate position that must be changed, if it wishes to be truly in line with tradition and with the fundamental principles of the religion it claims to represent.

However, expectations of the state changed once it became clear that rights to equal funding were not being upheld. Religious seminaries for men (yeshivot) are given state funding if they meet requirements concerning curriculum and the time the students spend studying. Women's seminaries (midrashot), where women studied religious studies at a level comparable to men, were not awarded the same funding. One of these seminaries, Nishmat, petitioned the Supreme Court to force the state to recognize this discrepancy and rectify it (see: Nishmat vs. the Minister for religious affairs, Israeli Supreme Court Case 744/95). In this case, the expectation was that even if the religious establishment refuses to recognize change, that the state will do so. Indeed, in this case, the court (representing the state in this case), ruled that the minister for religious affairs (representing the religious establishment in this case ${ }^{9}$ and refusing to recognize that women's programs were comparable to the men's programs) should negotiate with Nishmat. They ultimately reached an agreement that the Supreme Court upheld (Nishmat vs. the Minister for religious affairs, Israeli Supreme Court Case 744/95). The agreement forced the religious authorities to recognize Nishmat (and consequently other women's study programs) and award them equal funding. This example indicates that when religious feminists perceive the situation as one where their external rights are being violated (funding vs. internal recognition of their right to study), it is only then that they have expectations from the state. The attempt to achieve internal rights and legitimacy do not include expectations from the state. In this 
respect, the case of Nishmat vs. The Minister for religious affairs does not utilize "rebellion" but rather another strategy noted below (leveraging).

Sered also described another strategy that it seems religious feminist adopt at times: revolt. Revolt is a strategy used similarly to rebellion, but it is utilized when the women involved feel there is no hope for true change from the inside (bottom-up). In other words, it is used when the issue at hand is internal (within the religious social sphere), has a clear dimension of religious law or practice, but religious feminists do not think the religious establishment will recognize their demands due to a fundamental disagreement as to the nature of change needed. In such cases, religious feminists revolt against the current religious authority and create an alternate authority. When using revolt, the expectation from the state is to recognize that the current situation is unacceptable legally and morally (and thus undemocratic). In this case, the appeal by religious feminists to the authority of the State is considered legitimate. In other words, the expectation from the state is to uphold the change created by religious feminists and recognize its legitimacy; not to create the change, but to recognize what has been constructed as a result of the revolt.

In the Israeli case, "revolt" as a strategy can be detected as being used in two main spheres, both concerning personal status. Since, as noted above, in Israel marriage and divorce are controlled exclusively by religious authorities, all Jewish personal status is decided through the Chief Rabbinate and its rabbinical courts (Halperin-Kaddari 2004, ch. 11). Women who are not granted a religious divorce (get), may not remarry and civil divorce does not exist. The power to grant a religious divorce is given exclusively to the husband, and without his consent, the wife cannot remarry or have children out of wedlock. ${ }^{10}$ If a woman does enter a relationship and have children, the relationship will not be recognized by the state and her children will not be able to marry in Israel. While Jewish Law has given religious courts tools with which they can circumvent extreme cases when a husband insists on "chaining" his wife to a dead marriage making her an "aguna", many women's organizations feel the rabbinical courts are reluctant to utilize these tools (Lubitch 2017). One such organization, the Center for Women's Justice (CWJ), has created private religious courts to deal with such extreme cases (see the organization's website: < http://cwj.org.il/news/596>). These courts are not part of the Rabbinate 
and in three cases so far have been able to release women from marriages that the rabbinical courts have failed to resolve for extended periods (Rabinowitz 2018; Nahshoni 2018; 2020; Nahshoni and Twizer 2019). In these cases, the expectation from the state is to recognize these divorces and enable the women to remarry and have their marriages recognized by the state, should they choose to do so. In turn, this will mean recognizing their future children as legitimate (that is: eligible for marriage). ${ }^{11}$ At the moment, it is not clear where the state will stand in such cases. If these women do indeed remarry and have children, the issue will become pertinent.

The second sphere where revolt as a strategy can be detected is very much a bottom-up movement and involves couples who refuse to register their marriages through the Rabbinate. They conduct private ceremonies (considered illegal in Israel) and then choose whether to register as married in the Ministry of Interior. ${ }^{12}$ In these cases too, the expectation from the state is to recognize these marriages, even when conducted in Israel without the official approval of the Rabbinate, and afford the couples all the rights rabbinate-sanctioned marriages are given. Presently, the state recognizes such marriages only if the couple marries abroad and then returns to Israel with a foreign marriage certificate. ${ }^{13}$ In all of these examples, the revolt is aimed at the Rabbinate, perceived as an agent of the religious establishment. While at present there is no clear call from religious feminists upon the state to change legislation, though this might happen, the expectation is that the State will nevertheless move to accept these marriages. This will require a change in legislation and a breach of the Millet system. It is important to stress that both revolution and revolt do not turn to external actors in order to work change. When used, these strategies are internal actions, as opposed to leveraging, where the external actor is the key to using this strategy successfully (as described below).

\section{b. Exit, Voice and Loyalty}

Exit as a strategy is borrowed from Allen Hirschman (1970; 1974; Saunders, 1992) and his theory of exit, voice and loyalty, and the subsequent studies based upon these terms. This theory posits that when consumers (believers, citizens, employees) are unhappy with their current relationship with the organization they belong to (a given church, state, employer), they can either exit, meaning, leave for 
a better option (another church/religion/denomination, emigrate, a different job), or they can voice, express their position and try to change the system from within. Exiting is an economic action (choosing a better option from those that exist in the market). Voice is a political action (protest, advocating for change). Loyalty is an added dimension that influences the likelihood of an individual to "exit" or "voice". In this context, the more a consumer is loyal to the organization, the more s/he will be inclined to voice rather than exit. The more a consumer is disenchanted with the organization and feels neglected by it (seen as being the opposite of "loyalty"), the more s/he will be inclined to exit, rather than voice. These terms are based on cost-gain analysis of the consumers. It assumes that consumers are exclusively motivated by cost-gain considerations.

In subsequent studies, Hirschman raised further thoughts concerning when consumers choose to voice and when they choose to exit, indicating that voice is preferred many times to exit (Hirschman, 1974). This is primarily because while it was previously thought that exit has little or no cost whereas voice is usually costly, in truth exit can also be costly. For example, exiting a marriage when one has assets and children might be far more costly than a sincere attempt to save the marriage actively (voice). Obviously, these are helpful initial terms (even when presented here in a simplified manner), but they require reshaping and adapting to be useful in examining the methods used by religious feminists. Voice is not a single strategy for religious feminists and seems to include options that are not limited to revolt and rebellion.

Exit is likewise a complicated strategy when seen in the context of religious feminism. Hirschman presupposes that exiting is an option and that in a market environment, consumers can always opt to leave in favor of a better option. But in an environment where the state has dictated the power of the religious authorities, and given the particular dynamic between believers and religion, this assumption does not apply in the same manner. Contrary to the idea put forward by political economists (Gill, 2001, Stark, 1984), religious individuals do not always accept that they have a choice as "consumers" of goods, in the sense that they believe with utmost internal conviction that the religion they belong to is "true" and "correct". Simply picking another god, or another interpretation of God, is rarely considered an option. When a religious construct is accepted by believers as being "true", exit cannot 
equate a complete separation. It might, however, take on different forms. Where political economists see a market, believers see a complex network of dimensions. To ignore these and view the relationship as purely economic is limiting. It may seem convincing on a theoretical level but lacks a multi-level understanding of belief. As shown by Stark (1984), viewing religion as a disconnected variable is unhelpful and only within context do we truly understand its implications.

Furthermore, for many religious feminists, exiting in the sense of leaving the current situation and searching for an alternative to the current religious framework they belong to, may not be an option. There are several reasons, including: their belief in a specific religion or denomination with all the social implications this includes, despite developing strong negative feelings regarding the religious establishment; being partnered with someone who remains inside the particular religious framework or denomination; being socially imbricated within the particular organization (such as through employment, or by virtue of children in schools or in marriages, etc.). Moreover, their identity is based upon their being religious feminists. General society tends to dismiss their demands, advising religious feminists to exit. ${ }^{14}$ For religious feminists, this call to exit is insulting and misunderstands their position. In economic terms, even when the market has more options, it does not predict exiting for religious feminists due to the fact that belonging to a religious denomination has many social implications as well as religious ones, and is an important component of their personal identity.

That is not to say that no religious feminists choose exit in the sense of leaving religion. Toward the end of 2019 and the beginning of 2020, a very small number of members of the popular Israeli religious feminist facebook group "I too am a *religious* feminist with no sense of humor" announced they no longer saw themselves as religious. Yet the broad tent of social belonging that constitutes the religious space, even when it is not supported by concomitant practice or belief, can be seen in the fact that they nevertheless remained in the facebook group. ${ }^{15}$ There are also those who chose to leave orthodoxy, and turn to Reform or Conservative Jewish communities. But these are small and isolated cases for the most part. A more accepted form of exit is to minimize contact with formal religion. For example, not coming to pray regularly at a synagogue so as not to have to face the feelings of discrimination in the public sphere. While continuing to observe religious traditions 
in the home or other public spaces. While this is not exiting completely, it can be seen as a form of exit in this particular institutionalized context.

For theoretical purposes, "exit" can nevertheless be considered a strategy. Exiting occurs when there are no longer any expectations from the religious establishment and the exiting individual no longer wishes to be a part of the current institutional religious framework. In such an environment, there are no expectations from the state regarding the tensions between religion and the state: those who choose to exit see themselves as individuals making an individual choice and are "opting out". They may still be preoccupied by feminist or social issues, but the religious dimension no longer exists. Therefore, they have no expectations from anyone in the religious context: neither the religious establishment nor the state.

\section{c. Acceptance}

In addition to these two term clusters, additional strategies prove helpful. One of these is Acceptance: accepting the current situation and not attempting to change it, neither exiting, nor gaining voice; neither rebellion nor revolt. This strategy can be adopted either due to agreement with the current reality or accepting it as the only religiously viable option, or due to the fact that religious women and activists involved fear there is no hope to bring about change. Acceptance may seem like defeat, or abandonment of principles and efforts of religious feminists. But if there is no way to change the religious establishment in the current context believers may resign themselves to the existing reality, seeing no other choice and preferring it to exiting. For example, women may accept that they are unable to serve in positions of religious leadership because their religion at its core cannot accept this, even if they continue to hope for female representation. Another option is to accept the current situation while seeing it as desirable (for example, when women agree that women cannot be religious leaders, and religious rulings to this effect are correct), and so on. ${ }^{16}$

Acceptance is different from strategies suggested by Hirschman and Sered in that it does not necessarily see the situation itself as "right" or "correct" or, conversely as "wrong". It is resigning oneself to reality and, at times, trying to rationalize it, but such rationalization is not a requirement. 
It is equally possible to "accept" and still see reality as "unfair" or a "misinterpretation". Accordingly, there also might be types of acceptance: acceptance when one is able to rationalize the religious position and identify with it and cases when one is unable to identify with the current reality.

No matter which type of acceptance is used, in this case, there are no expectations from the state. Acceptance is used vis-à-vis the religious establishment alone. Since this is possibly the most prevalent strategy, and involves the acceptance of the current internal status quo, the state does not play a part within it. It is only when change is demanded that expectations from the state can come into play.

\section{d. Bargaining}

Another strategy, that seems to be developing in the past decade, is bargaining, in a form similar but not identical to the theory coined by Deniz Kandiyoti $(1988 ; 2005)$. Kandiyoti demonstrated how women are willing to forego part of their independence in exchange for social dividends. They are willing to accept certain patriarchal dictates in exchange for other rights. For example, a woman may agree to dress traditionally in exchange for being allowed to study at a university or work outside the home.

Since its publication, it seems that this strategy has evolved. Women can see themselves as an independent force, able to negotiate with official religious authorities, and offer trade-offs in exchange for legitimacy. Religious feminists may utilize bargaining in dealings with religious authorities in cases where they are supported by social changes arguing in favor of a specific change within the religious sphere of influence. In other words, when it seems there is popular support for an internal change within a religious group and that religious authorities sense this bottom-up social shift, religious feminists can offer trade-offs in order to accelerate legitimation for a certain practice. In such cases, the demand from the state will be to adopt a hands-off approach and not interfere, but enable the change sought and support it, should such support be needed. Similarly to rebellion, having the state not interfere, lends credibility to the demands. However, unlike the case of rebellion, in the case of bargaining, religious feminists expect the state to be a silent partner, cooperating behind the 
scenes in order to allow change to take place. On the other hand, the religious establishment will usually see bargaining as a lesser evil. Since its authority is not being questioned, and the women involved still frame themselves as beholden to it, striking a bargain may seem as the best alternative. Bargaining as a strategy has been used in Israel concerning military service of religious women (Rosman-Stollman 2018). The state does not require religious women's conscription and the religious authorities have banned it and yet religious women enlist. However, since the late 1990s, they tend to enlist through pre-military preparatory seminaries of various forms and gravitate toward "pink collar" military postings - military jobs that are more feminine and less combat-oriented: education NCOs, instructors and military intelligence postings (Rosman-Stollman 2018). In enlisting through recognized religious programs, these women signal that they are willing to forfeit part of their freedom to choose military postings that might be more interesting or challenging, in exchange for legitimacy in the eyes of the religious establishment.

In this context, the expectation from the state in the Israeli case, is to allow the pre-military programs to exist so that religious women may enlist in a way that is conducive to their religious observances. A support system within the military must be available and recognition that these women are dealing not only with military service, but also with pressures from their social group.

In addition, the expectation is that the state will support religious women who enlist and not encourage efforts on part of the religious frameworks to oppose their enlistment. For example, some religious schools for girls pressure their students to refrain from enlisting and to sign release forms proclaiming that they are unable to enlist due to their religious beliefs. They organize mass-signings in order to pressure the students who might otherwise enlist. Religious women's organizations have petitioned the state to rule these efforts as illegal (Cohen 2017).

\section{e. Leveraging}

Yet another strategy, sometimes used in tandem with one of the other strategies, is leveraging. This, too, is a strategy yet to be noted in scholarship. In this strategy, religious feminists use the state as leverage in order to force the religious establishment to accept a deal. It differs from bargaining in 
that it uses an external entity (in many cases the state and the judicial system) in order to force the religious establishment to retreat or concede, and a tradeoff is not offered. ${ }^{17}$ There is no expectation that religious authorities will lend legitimacy to the change (as opposed to the result in bargaining), only that the change will take place and that religious authorities will be forced to accept it. This strategy has gained popularity (not only in Israel), especially in legal-political issues such as obtaining a religious divorce, after a civil divorce is acquired.

In such cases, the state is the most important variable. Religious feminists turn to the state, mainly through the judiciary, forcing the religious establishment to agree to certain terms. At times, it is in exchange for religious feminists rescinding their appeal to the state, or in exchange for accepting concessions on the part of the religious authority. However, an exchange is not imperative, and many times the legal ruling will stand with no way for the religious establishment to save face. Such a strategy will be utilized when the issue at hand is internal (within the religious sphere) but has a clear external aspect (involving secular women or involving civil rights, not just religious ones) and the religious establishment has indicated it is unwilling to negotiate any form of change. In these cases, the expectation from the state is the most vocal of all other strategies. Religious feminists expect the state to stand by its commitment to them as equal citizens and protect their rights versus the religious authorities.

As noted above, to a certain extent, leveraging as a strategy was used in the Nishmat case. In this case, an agreement was reached in exchange for Nishmat withdrawing their petition. An example where no trade-off was offered is the Supreme Court case Itim and others vs. The Minister for Religious Affairs and others (5022/15) when a group of religious women in Jerusalem petitioned the Supreme Court to force the Chief Rabbinate in Jerusalem to allow them to use state-funded ritual baths without supervision (Perez and Rosman 2019). Use of religious baths (mikvaot) is a fundamental requirement of an orthodox household in Judaism (for an extensive explanation see: Perez and Rosman 2019). In Israel, these baths are funded by the state and operated by local religious councils. The bath attendants (balaniyot) regulate the use of the baths and are known to assert their power over the women using them, sometimes overruling the women's personal observances. The 
women who petitioned the Supreme Court saw it as an agent of the state (as in the Nishmat case) and expected it to uphold their rights as tax-paying citizens to have access to the baths and use them in the manner that their personal religious observances dictated. They saw the Ministry of religious affairs as an agent of the religious establishment: forcing women to adopt the most stringent interpretation of how to use the baths (Itim vs. The Ministry of religious affairs, 5022/15). ${ }^{18}$ Interestingly, the Ministry of Religious Affairs realized it would not be able to defend the position of the religious establishment in court. It therefore notified the Court it would be accepting the women's position: no trade-off was offered, and the Ministry withdrew unceremoniously from its previous position. This left the Rabbinate in Jerusalem, the main agent of the religious establishment, as the sole defendant in the case. Realizing it would not be able to defend itself, it also accepted the women's demands (Itim and others vs. The Ministry for religious affairs 5022/15). ${ }^{19}$ Again, as opposed to the example of women's conscription and the use of bargaining in general, when using leveraging, religious feminists do not expect their actions to be seen as legitimate and do not always offer a tradeoff. They wish change to occur and feel they have nothing to lose.

This example indicates that when brought into the equation, the state plays an important role in the relationship between religious feminists and the religious establishment. It also demonstrates that religious feminists are able to convey their expectations to the state and that there are cases where they prefer the state not interfere. In turn, this is what makes leveraging a powerful tool.

\section{Discussion}

After describing the possible strategies, it is possible to construct a typology (see Table 1). These range from Acceptance to Exit. This typology should be seen as a preliminary one. Some of these strategies can be broken down further. For example, as noted above, "acceptance" seems to include positive acceptance (seeing the current situation as positive and not wishing to change it), negative acceptance (seeing the current situation as negative, but deciding that change is impossible [at this time, permanently or any other range of time] and therefore accepting it) and perhaps additional subcategories. This should be done with the help of other case studies. 
Table 1: Typology of Strategies

\begin{tabular}{|l|l|l|l|}
\hline & $\begin{array}{l}\text { When expected to } \\
\text { surface }\end{array}$ & $\begin{array}{l}\text { Religious Feminist } \\
\text { Expectation from } \\
\text { the State }\end{array}$ & Description of strategy \\
\hline Acceptance & Most of the time & None & $\begin{array}{l}\text { Acceptance of the status quo } \\
\text { with no attempt for change }\end{array}$ \\
\hline Bargaining & $\begin{array}{l}\text { Internal issues where } \\
\text { there is a chance of } \\
\text { change due to social } \\
\text { shifts from below }\end{array}$ & $\begin{array}{l}\text { Enabling change } \\
\text { when needed }\end{array}$ & $\begin{array}{l}\text { Internal action versus the } \\
\text { religious establishment, where } \\
\text { X is offered in exchange for Y }\end{array}$ \\
\hline Leveraging & $\begin{array}{l}\text { Internal issues that have } \\
\text { a clear external aspect } \\
\text { together with a } \\
\text { reluctance of the } \\
\text { religious establishment } \\
\text { to change }\end{array}$ & $\begin{array}{l}\text { Actively protect } \\
\text { women's equal } \\
\text { rights as citizens }\end{array}$ & $\begin{array}{l}\text { Using the state in order to } \\
\text { force the hand of the religious } \\
\text { establishment. Usually using } \\
\text { the courts. Trade-off may or } \\
\text { may not be offered. }\end{array}$ \\
\hline Rebellion & $\begin{array}{l}\text { Internal issues within } \\
\text { the religious } \\
\text { establishment's sphere } \\
\text { of influence. There is } \\
\text { an aspect of religious } \\
\text { law involved }\end{array}$ & $\begin{array}{l}\text { most cases. Enable } \\
\text { change }\end{array}$ & $\begin{array}{l}\text { Creating change from within, } \\
\text { without questioning the } \\
\text { religious establishment's } \\
\text { authority. Usually claiming the } \\
\text { change is not a real change but } \\
\text { rather has traditional roots, or } \\
\text { is not prohibited }\end{array}$ \\
\hline Exit & $\begin{array}{l}\text { Internal issues with an } \\
\text { external aspect and a } \\
\text { clear religious } \\
\text { dimension, where there } \\
\text { is no hope for change }\end{array}$ & $\begin{array}{l}\text { Rarely } \\
\text { alternate authority } \\
\text { as legitimate }\end{array}$ & $\begin{array}{l}\text { Refusing to accept the authority } \\
\text { religious authority and revolting } \\
\text { against it. Creating an alternate } \\
\text { authority with alternative } \\
\text { interpretations of religious law }\end{array}$ \\
\hline Revolt & $\begin{array}{l}\text { Rejecting the current reality } \\
\text { and unwillingness to live } \\
\text { within it }\end{array}$ \\
\hline
\end{tabular}

Clearly the typology allows for a better understanding of the relationship between religion, the state and religious feminists. It also offers a theoretical prism through which to view expectations from the state. When turning to the State, it seems that religious feminists in Israel do not expect it to create change, for example by creating new legislation. Expectations from the state are mainly reactive: support a change that has been made, protect existing rights. Therefore, expectations are limited to support and do not demand initiative.

Additionally, the main tool used to convey expectations for action is the courts. While there are members of Knesset who at times advocate for religious feminist issues, ${ }^{20}$ they do not classify themselves as representatives of religious feminism. Legislation relevant to issues of religious 
feminism is difficult to detect and in any case is not portrayed as such. Therefore, while religious feminists address the religious establishment using various tools, the main tool through which they enlist the support of the state is legal action.

This is not surprising. Religious feminists, for the most part, wish to remain within the existing orthodox, framework. Involving the State in a more active role would be seen as an illegitimate move. In order to create change, religious feminists must weigh strategies and choose between them; rarely choosing revolt (and exit) in order to conserve the weight of these strategies and use them only when they will have the most desired effect.

It is entirely possible that in the future, religious feminists will expect more proactive steps on the part of the state. For example, there might be a call for more active church-state separation in Israel, or for legislation forcing certain changes in family law in order to bypass the religious court system. As of 2020, this has yet to happen. However, if any movement has the ability to bring about such change, it is religious feminism. Accepting the religious establishment as a legitimate actor, using the same terms and tools as it uses, allows religious feminists to negotiate and bargain, to pressure and shape rules, and - ultimately - to change reality.

The current paper was not able to focus on religious feminist organizations or organizations that find themselves dealing with religious feminist issues. Since religious feminists in Israel do not necessarily need to belong to formal organizations in order to act, the paper focused on a broader view of women who are religious feminists and have expectations vis-à-vis the state. This is not to say that these organizations do not exist or are not important. Future studies must address the way organizations choose strategies and if there are differences between how individuals and organizations choose strategies and their expectations from the state.

Likewise, it is beyond the scope of the current paper to include an in-depth examination of other countries. However, two examples should be sufficient in order to encourage future discussion. When religious feminists in the Netherlands turn to civil courts in order to pressure religious courts to force husbands to release wives from religious marriages, they are utilizing leveraging. They are not 
offering trade-offs, but forcing the religious authorities to do something they would rather not do, due to pressure applied by the state (Eijk, 2015).

Leszczynska (2016) demonstrates convincingly, how practicing Catholic women in Poland, who can be defined by others (but not themselves) as feminist, are use acceptance as a coping mechanism. While she does not use this term, placing the women in her study within the context of the proposed typology, allows for better understanding of their motives and behavior. The study presents a seemingly puzzling view of deeply religious women, most of whom are independent, educated, hold prestigious positions in their personal lives, and are influential within religious frameworks, yet completely internalize the Church's position on gender inequality. When viewing these findings as acceptance (perhaps positive acceptance), they are far less perplexing and are in context.

It is still unclear if feminists from a specific religion prefer specific strategies over others. Likewise it remains to be seen if perhaps religious feminists from different countries have preferred strategies and if this can be connected to political culture or political climate. The proposed typology now requires solidification and further exploration.

\section{Conclusion and Thoughts on Future Scholarship}

This paper proposes tools with which to analyze the relationship between religious feminists, the state and religious authorities. In light of the accelerated activities of religious feminists since the mid1990s, it is time scholarship developed tools with which to understand this phenomenon. The current paper's contribution lies in proposing a typology with which to analyze this relationship and discern what religious feminists expect from the state and how they relate to it. While it is still preliminary, it sets the foundation for further studies.

Future studies will hopefully expand this typology and build upon it. Examining it, for example, from the point of view of the state: how does the state view these expectations? When does it involve itself in the relationship between women and religion and when does it prefer to remove itself? Can strategies be detected in this context as well? Such questions will also improve the understanding of religious feminist strategies, and perhaps general feminist strategies vis-à-vis the state. 
Additionally, comparative work is sorely needed. While the current paper examines the typology from the point of view of the case study (Israel), testing it using other cases is necessary. For example, the Netherlands can serve as a case where the majority religion (Protestant Christianity) does not pose the main point of contention between religious feminists, religion and the state, but rather minority religions (Islam and Judaism) enlist the state's support, and receive it. ${ }^{21}$ Turkey, where the majority religion (Sunni Islam) is officially separated from the state, but in practice maintains a complex church-state relationship, is an important case (Aksoy, 2015). Comparing these cases, as well as others, will allow for a better understanding of strategies and will also undoubtedly develop the proposed typology. In turn, this will allow us to better understand the relationship between religious individuals and the state. In a world where religion continues to be an important force, this topic cannot be underestimated.

\section{References}

Israeli Supreme Court Cases

Itim and others vs. the Minister for Religious Affairs and others (5022/15)

Leah Shakdiel vs. the Minister for Religious Affairs and others (153/87)

Nishmat vs. the Minister for Religious Affairs (744/95).

Books and Articles

Ahmed, F.(2010). Personal autonomy and the option of religious law. International Journal of Law, Policy and the Family, 24(2):222-244.

Aksoy, H. A. (2015). Invigorating democracy in Turkey: The agency of organized Islamist women. Politics \& Gender, 11(1), 146.

Artzi-Sror, C. (2018). The New Religious Women: Religious Feminism Meets Social Media, Yediot Aharonoth [Hebrew].

Aune, K., \& Nyhagen, L.(2016). Religion, politics and gender. Routledge Handbook of Religion and Politics. New York: Routledge.

Avishai, O., Jafar, A., \& Rinaldo, R.(2015). A gender lens on religion. Gender \& Society, 29(1):525.

Barak-Erez, Daphne (2009). "Law and Religion under the Status Quo Model: Between Past Compromises and Constant Change", 30 Cardozo Law Review: 2495-508.

Bowie, F. (2016). Negotiating Blurred Boundaries: Ethnographic and Methodological Considerations. The Insider/Outsider Perspective in the Study of Religion. Sheffield: Equinox. Bowie, Fiona (2016b), 152-200.

Casanova, J., \& Phillips, A.(2009). A debate on the public role of religion and its social and gender implications. Geneva: United Nations Research Institute for Social Development.

Castelli, E., \& Rodman, R. (Eds.)(2001). Women, gender, religion: A reader. Springer.

Center for Women's Justice (2020). "Facebook post," Facebook < https://www.facebook.com/cwjisrael/posts/2928197670552749? tn =K-R> [Hebrew], 4 March, 2020 (accessed: March 2020). 
Cohen J.L. and C. Laborde (eds.) (2016), Religion, Secularism and Constitutional Democracy, Columbia University Press.

D’Costa, G., et. Al (eds.) (2013). Religion in a Liberal State, Cambridge University Press.

Eijk, Esther van. (2015). "Khul 'divorce in the Netherlands: Dutch Muslim women seeking religious divorce." In American Anthropological Association annual meeting, Denver, CO. 2015.

Elor, Tamar (1998). Ba-Pessach Ha-ba (Next Pessach: Literacy and Identity of Young Religious Zionist Women). Tel Aviv: Am Oved, 1998 [Hebrew].

Gerber-Aran, Efrat (2019). "I've left the Aron Kodesh," Facebook < https://www.facebook.com/efrat.garber/posts/10157609054039324> (26 Sep. 2019), (accessed: February, 2020) [Hebrew].

Gill, A. (2001). Religion and comparative politics. Annual Review of political science, 4(1), 117-138.

Haddad, Y.Y., \& Esposito, J.L.(2001). Daughters of Abraham Feminist Thought in Judaism, Christianity, and Islam.

Halperin-Kaddari, R.(2004). Women in Israel: A state of their own. University of Pennsylvania Press.

Halperin-Kaddari, R.(2000). Women, Religion and Multiculturalism in Israel. UCLA J. Int'l L. \& Foreign Aff., 5,339.

Herzog, H., \& Braude, A.(2009). Gendering religion and politics: Untangling modernities. Springer.

Hirschman, A. O. (1970). Exit, voice, and loyalty: Responses to decline in firms, organizations, and states (Vol. 25). Harvard university press.

Hirschman, A. O. (1974). " Exit, voice, and loyalty": Further reflections and a survey of recent contributions. Information (International Social Science Council), 13(1), 7-26.

Hirschman, A. O. (1978). Exit, voice, and the state. World Politics, 31(1), 90-107.

Htun, M., \& Weldon, L.(2012). Sex equality in family law: historical legacies, feminist activism, and religious power in 70 countries.

Hawley, J.S. (Ed.)(1994). Fundamentalism and gender. Oxford University Press on Demand.

Irshai, R. (2012). Exclusion of Women-Feminism as the sad Winner. Jerusalem: the Israeli Institute for Democracy [Hebrew].

Irshai, R. (2010). Toward a Gender Critical Approach to the Philosophy of Jewish Law (Halakhah). Journal of Feminist Studies in Religion, 26(2), 55-77. doi:10.2979/fsr.2010.26.2.55

Israel-Cohen, Y. (2012). Between feminism and Orthodox Judaism: Resistance, identity, and religious change in Israel (Vol. 20). Brill.

Karayanni, Michael M. (2014). "The Multicultural Nature of the Religious Accommodations for the Palestinian-Arab Minority in Israel: A Curse or a Blessing?”, in René Provost (ed.), Mapping the Legal Boundaries of Belonging: Religion and Multiculturalism from Israel to Canada (Oxford: Oxford University Press).

Kandiyoti, D. (1988). Bargaining with patriarchy. Gender \& society, 2(3), 274-290.

Kandiyoti, D. (2005). Rethinking bargaining with patriarchy. Feminist vision of development: Gender, analysis and policy, 135-154.

Kuru, A.T. (2009). Secularism and state policies toward religion: The United States, France, and Turkey. Cambridge University Press.

Laborde, C. (2017). Liberalism's religion. Harvard University Press.

Laborde, C., \& Bardon, A. (Eds.). (2017). Religion in liberal political philosophy. Oxford University Press.

Leszczyńska, K. (2016). The (Self-) Exclusion of Women from the Roman Catholic Church in Poland. Polish Sociological Review, 196(4), 459-476.

Liebman, Charles \& Eliezer Don Yihya (1983). Civil Religion in Israel (Berkeley: University of California Press).

Liphshiz, Cnaan (2020). "In the Netherlands, judges can fine and lock up Jewish men who refuse to give their wives a religious divorce," The Jewish News of Northern California (19 Aug, 2020) < https://www.jweekly.com/2020/08/19/in-the-netherlands-judges-can-fine-and-lock-up-jewishmen-who-refuse-to-give-their-wives-a-religious-divorce/> (accessed: Aug. 2020).

Llewellyn, D., \& Trzebiatowska, M. (2013). Secular and religious feminisms: A future of disconnection?. Feminist Theology, 21(3), 244-258. 
Lubitch, R (2017). From the End of the World and Beyond: The Long, Hard Road of Women's Sufferings in Israeli Rabbinic Courts, Miskal [Hebrew].

Nahshoni, K. (2018), "In a Unique Act: Private Rabbinic Court Annuls Marriage of Get Refusee," Ynet, 24 July, 2018 < https://www.ynet.co.il/articles/0,7340,L-5315418,00.html>, accessed: Feb. 2020 [Hebrew].

Nahshoni, K. (2020). "Rabbinic Court Annuls marriage after 15 Years: 'The Couple never Consummated their Marriage'," Ynet, 16 Jan. $2020<$ https://www.ynet.co.il/articles/0,7340,L5660835,00.html>, accessed: Feb. 2020 [Hebrew].

Nahshoni, K. and I. Twizer (2019). "A Precedent is Set: Marriage of a Get Refusee Annulled due to a 'Mistake'," Ynet, 4 Feb. 2019 < https://www.ynet.co.il/articles/0,7340,L-5457448,00.html>, accessed: Feb. 2020 [Hebrew].

Neuberger, B. (1999). "Religion and state in Europe and Israel", 6(2) Israel Affairs: 65-84.

Nyhagen, L. (2019). Contestations of feminism, secularism and religion in the West: the discursive othering of religious and secular women. Nordic Journal of Religion and Society, 32(01), 4-21.

McLoughlin, S., \& Cesari, J.(Eds.(2016). European Muslims and the secular state. Routledge.

Monsma, S.V., \& Soper, J.C.(2009). The challenge of pluralism: Church and state in five democracies. Rowman \& Littlefield.

Moors, A. (2009). The Dutch and the face-veil: The politics of discomfort. Social Anthropology, 17(4), 393-408.

Okin, S. M. (1998). Feminism and multiculturalism: Some tensions. Ethics, 108(4):661-684.

Okin, S. M. (2002). "Mistresses of their own destiny": Group rights, gender, and realistic rights of exit. Ethics, 112(2):205-230

Ozcetin, H. (2009). 'Breaking the silence': the religious Muslim women's movement in Turkey. Journal of International Women's Studies, 11(1), 106-119.

Perez, N. (2020). What Are Data Good for Anyway?: A Typology of Usages of Data in Contemporary Political Theory. Social Theory and Practice.

Perez, N. and Rosman, E. (2018), "Balaniyot, Baths and Beyond: Israel's State-Run Ritual Baths and the Rights of Women," Journal of Law, Religion and the State.

Rabinowitz, A. (2018). "After 17 years, The Aguna Revoked Her charges against Get Refuser," Haaretz, 24 Oct. 2018 < https://www.haaretz.co.il/news/law/1.6592212>, accessed: Feb. 2020 [Hebrew].

Razavi, S., \& Jenichen, A. (2010). The unhappy marriage of religion and politics: Problems and pitfalls for gender equality. Third World Quarterly, 31(6), 833-850.

Rosman-Stollman, E. (2018). Military service as bargaining: the case of religious women soldiers in Israel. Politics, Religion \& Ideology, 1-18.

Rosman, E. (2018). (Not) Becoming the Norm: Military Service by Religious Israeli Women as a Process of Social Legitimation. Israel Studies Review, 33(1), 42-60.

Ross, Tamar (2004). Expanding the Palace of Torah: Orthodoxy and Feminism. Waltham, MA.: Brandeis University Press, 2004.

Schnabel, L. (2017). Gendered Religiosity. Review of Religious Research, 59(4):547-556.

Sered, S. 1997. "Women and Religious Change in Israel: Rebellion or Revolution," Sociology of Religion, 58(1): 1-24.

Shachar, A. (2005). Religion, State, and the Problem of Gender: New Modes of Citizenship and Governance in Diverse Societies. McGill LJ, 50, 49.

Saunders, D. M. (1992). Introduction to research on Hirschman's Exit, Voice, and Loyalty model. Employee Responsibilities and Rights Journal, 5(3), 187-190.

Sommer, A. K., \& Lithwick, D. (2013). They Are Orthodox, Hear Them Roar. New Republic, 244(13), 16-21.

Stopler, G. (2005). The liberal bind: The conflict between women's rights and patriarchal religion in the liberal state. Social Theory and Practice, 31(2):191-231.

UNRISD (2007), Religion, Politics and Gender Equality - Project Site <http://www.unrisd.org/80256B3C005BB128/(httpProjects)/3F3D45E0F8567920C12572B9004 180C5>, accessed: March 2018. 
Watling, T. (2002). 'Leadership'or 'Dialogue'? Women, Authority and Religious Change in a Netherlands Community. Sociology of Religion, 63(4), 515-538.

Wolowelsky, J. B. (Ed.). (2001). Women and the Study of Torah: Essays from the Pages of Tradition. KTAV Publishing House, Inc..

Yanay-Ventura, G. (2016). Multifaceted Religious Feminism-The Case of Modern Orthodox Feminists in Israel. Sociol. Anthropol, 4, 17-28.

Yuval-Davis, Nira. 2011. The politics of belonging: Intersectional contestations. Sage.

\begin{abstract}
${ }^{1}$ The term religious feminist can include many individuals. For the purpose of this paper, a religious feminist is a person who classifies herself as religious (regardless of religion) in the sense that religious identification is a fundamental component of her identity, and who struggles with the way her religion frames women and their place within the religious fold. In many cases (but not always), she also seeks to promote and recognize women's places and roles within this religion. (These individuals can include men who see themselves as feminists.)

${ }^{2}$ In the context of this paper, the religious establishment includes the most prominent and vocal main religious individuals and institutions that influence the public position a given religious presents. This includes - but is not limited to - the religious authorities recognized by a given state.

${ }^{3}$ This position has been questioned by a number of recent studies see for example: Nyhagen, 2019; Llewellyn, D. and

Trzebiatowska, M., 2013.

${ }^{4}$ Such as (but not limited to) Alice Miller vs. the Minister of Defence and others (4541/94); Leah Shakdiel vs. the Minister of Religious Affairs and others (153/87).

${ }^{5}$ The author served as a member of a municipal religious council during the years 2007-2008, 2009-2018. During this time, she also headed a women's committee in charge of the ritual baths in her community. In this capacity, she was able to observe the way religious feminists used various strategies on the both the municipal and national level.
\end{abstract}

${ }^{6}$ The Millet system applies to all religious groups in Israel, see: Karayanni, 2014.

${ }^{7}$ These range from women who are non-Orthodox, but still consider themselves religious, to ultra-orthodox women and many sub-categories in between. One may also argue that this category includes traditional (mesorti) feminists. Sadly, a comprehensive description of religious-feminist organizations and groups is beyond the scope of this paper.

${ }^{8}$ For some of the debates regarding these issues see: Wolowelsky, 2001; Ross, 2004; Artzi-Sror, 2018; Elor, 1998.

${ }^{9}$ During the time of the verdict, the Minister for religious affairs was MK Eliyahu Swisa, of the ultra-orthodox SHAS party. Traditionally, the ministry for religious affairs is held by religious members of Knesset (parliament) in Israel and upholds the more stringent interpretations of Jewish orthodoxy. In this, it is more representative of the religious establishment than of the state itself. I therefore consider it in these cases as an agent of the religious authorities rather than of the state. This is also the way religious feminists perceive it, as can be seen from the way they address it in court. Conversely, the Supreme Court is regarded by religious feminists as an agent of the state and therefore is treated as such in this paper.

${ }^{10}$ For descriptions of the way rabbinical courts function, see: Lubitch 2017; Halperin-Kaddari 2004, ch. 11.

${ }^{11}$ According to Jewish law, a married woman who has children with a man who is not her husband gives birth to mamzerim. A mamzer and his/her offspring may only marry another mamzer or a convert to Judaism; thus limiting their marriage options significantly.

${ }^{12}$ In the cases where they choose to register, a civil marriage outside of Israel must take place.

${ }^{13}$ In the past decade, it has become more acceptable for couples who would be able to marry through the rabbinate (Jewish according to Orthodox halakha, heterosexual, couples), to marry outside the Rabbinate (Halperin-Kaddari, Fuchs and Rosman, forthcoming).

${ }^{14}$ For some examples of such discourse, see multiple discussion in the facebook group "I too am a *religious* feminist without a sense of humour", where this issue is discussed. (for just two recent examples: https://www.facebook.com/groups/352850698102983/permalink/353262944728425/; https://www.facebook.com/groups/352850698102983/permalink/3017862974935062/). For an example outside of Israel, see Muslim feminists' experiences as depicted in Okuyan and Curtin, 2018.

${ }^{15}$ See for example, Efrat Gerber-Aran's public post about her experience as well as subsequent posts on her page. She continues to be active in the aforementioned group: < https://www.facebook.com/efrat.garber/posts/10157609054039324>.

${ }^{16}$ This may seem like an impossible option for feminists. However, religious feminists might still see themselves as feminists, yet claim that religious rulings are binding and that religious feminists must work within certain constraints. While secular feminists might see this as impossible, some religious feminists live within this paradox and accept it.

${ }^{17}$ Although a trade-off may be offered if leveraging is used together with bargaining.

${ }^{18}$ For leveraging in the local political sphere see the various attempts of religious women in the city of Beit Shemesh to pressure their municipality regarding women's presence in the public sphere: Sommer and Litchwick, 2013.

${ }^{19}$ While the Israeli case demonstrates this strategy can be successful, it does not always work. For example, Leyla Sahin petitioned the European Court of Human Rights (ECHR) to allow her to continue her studies at a state university despite covering her hair (Şahin vs. Turkey, ECHR application 44774/98). Şahin lost, but this indicates that this strategy 
is used. These cases are not the same, and the Şahin case attempted to use an international actor (the ECHR) as leverage vis-à-vis the state. However, the idea at the base of both actions is similar.

${ }^{20}$ Such as MK Revital Sweid, and past MKs Shuli Mualem and Aliza Lavie.

${ }^{21}$ For a recent example: Liphshiz 2020. 